\title{
Reperfusion in acute myocardial infarction. International Society and Federation of Cardiology and World Health Organization Task Force on Myocardial Reperfusion
}

Circulation 1994;90;2091-2102

Circulation is published by the American Heart Association. 7272 Greenville Avenue, Dallas, TX 72514

Copyright $\odot 1994$ American Heart Association. All rights reserved. Print ISSN: 0009-7322. Online ISSN: 1524-4539

The online version of this article, along with updated information and services, is located on the World Wide Web at:

http://circ.ahajournals.org

Subscriptions: Information about subscribing to Circulation is online at http://circ.ahajournals.org/subscriptions/

Permissions: Permissions \& Rights Desk, Lippincott Williams \& Wilkins, a division of Wolters Kluwer Health, 351 West Camden Street, Baltimore, MD 21202-2436. Phone: 410-528-4050. Fax: 410-528-8550. E-mail:

journalpermissions@1ww.com

Reprints: Information about reprints can be found online at http://www.lww.com/reprints 


\title{
Reperfusion in Acute Myocardial Infarction
}

\author{
International Society and Federation of Cardiology and \\ World Health Organization Task Force on Myocardial Reperfusion*
}

$\mathrm{S}$ tudies of the pathophysiology of acute myocardial infarction (AMI) have shown that in most patients a thrombus forms over a ruptured atheroma in the infarct-related coronary artery and obstructs the artery..$^{1-3}$ In some patients, spontaneous lysis of the thrombus occurs, but in others, the obstruction persists and results in necrosis of myocardium in the area of the heart supplied by the obstructed artery. If reperfusion is accomplished within a variable time window, the size of the infarction and the resultant mortality are decreased and myocardial function is preserved.4-6 This time window originally was thought to be only up to 6 hours, but subsequent studies have suggested that there is benefit, although less, up to 12 hours. ${ }^{7}$ In earlier studies, reperfusion was accomplished primarily by the direct intracoronary administration of thrombolytic agents. Subsequently, myocardial reperfusion has been achieved by the intravenous (IV) administration of thrombolytic agents, by direct percutaneous transluminal coronary angioplasty (PTCA), or by coronary artery bypass graft surgery (CABG).

A significant (approximately 25\%) decrease in mortality from AMI has been clearly demonstrated in several placebo-controlled clinical trials of thrombolytic agents in patients with evolving AMI. These trials have used streptokinase (SK) ${ }^{8-11}$; alteplase (a preparation of single-chain recombinant human tissue-type plasminogen activator, TPA)12,13; or anistreplase (anisolated plasminogen streptokinase activator complex, APSAC), which is an equimolar complex between Lys-plasminogen and SK. ${ }^{14,15}$ Table 1 displays the results of the larger trials. $5,6,8-10,16,17$ Several other thrombolytic agents have been extensively studied, including duteplase, a twochain preparation of TPA; urokinase; and a single-chain urokinase-type plasminogen activator (scu-PA, prourokinase). Many other agents are in various stages of development. In general, the side effects of thrombolytic agents are quite acceptable, considering the potential benefit.

The beneficial effects of early myocardial reperfusion with thrombolytic treatment are now well established. ${ }^{18}$ In addition, the early administration of acetylsalicylic acid (ASA, aspirin) has been shown to produce a 23\% reduction in mortality, ${ }^{11}$ and it is now administered routinely in addition to a thrombolytic agent. Unless there is a strong contraindication, oral ASA should be

Received April 5, 1994; revision accepted July 11, 1994.

Correspondence to Robert C. Schlant, MD, Emory University

School of Medicine, 69 Butler St SE, Atlanta, GA 30303.

(C) 1994 American Heart Association, Inc.

*For members, see "Appendix." used promptly whether or not thrombolytic therapy is used.

Direct PTCA and CABG have also been used successfully to achieve early coronary reperfusion in patients with AMI. ${ }^{19-24}$ In some trials, ${ }^{22-24}$ it has been suggested that such therapy, when feasible, is comparable or even superior to thrombolytic therapy.

The indications and contraindications to thrombolytic therapy in patients with AMI have been slowly evolving. Several conditions formerly considered to be contraindications to such therapy either are no longer considered to be a contraindication or are considered to be only a relative contraindication (Table 2 ). It has been estimated that only $20 \%$ to $25 \%$ of the 1.5 to 2 million patients hospitalized worldwide each year with AMI receive thrombolytic therapy but that at least twice as many patients might be eligible for such treatment. ${ }^{16}$

\section{Pharmacological Basis for Thrombolytic Therapy}

The fibrinolytic enzyme system in blood comprises an inactive proenzyme, plasminogen, which can be converted to the fibrinolytic enzyme plasmin by the physiological plasminogen activators TPA or urokinase-type plasminogen activator. Fibrinolysis is inhibited at the level of the activators (by plasminogen activator inhibitors) and at the level of plasmin (mainly by $\alpha_{2}$-antiplas$\mathrm{min}$ ). Physiological fibrinolysis is highly fibrin-specific as a result of specific molecular interactions between TPA, plasminogen, fibrin, plasmin, and $\alpha_{2}$-antiplasmin. ${ }^{25}$

\section{Thrombolytic Agents}

The IV administration of SK and plasminogen activators can dissolve relatively fresh blood clots in coronary arteries. Three thrombolytic agents are currently widely approved for IV administration to patients with AMI. These are SK, alteplase (TPA), and anistreplase (Table 3). Urokinase is also approved for such therapy in some countries, and its single-chain precursor (single-chain UPA, prourokinase) is under clinical investigation.

SK is a bacterial protein that forms a complex with plasminogen; this complex activates other plasminogen molecules to plasmin. The administration of SK produces a so-called "systemic lytic state," which is characterized by fibrinogen degradation and $\alpha_{2}$-antiplasmin depletion in circulating blood.

The standard dose in patients with AMI is 1.5 million U IV infused over 60 minutes. SK causes transient hypotension in many patients and is antigenic; it causes significant allergic reactions in a small percentage of patients, and its administration causes a rapid rise in anti-streptokinase antibody titer after about 4 to 7 days, 
TABLE 1. Placebo-Controlled Trials of Intravenous Thrombolytic Therapy in Patients With Acute Myocardial Infarction That Randomized More Than 500 Patients

\begin{tabular}{|c|c|c|c|c|c|c|c|}
\hline \multirow[b]{2}{*}{ Trial } & \multirow[b]{2}{*}{$\begin{array}{c}\text { Thrombolytic } \\
\text { Agent }\end{array}$} & \multicolumn{4}{|c|}{ Short-Term Mortality } & \multirow[b]{2}{*}{$\begin{array}{c}\text { Reduction, } \\
\text { Percent }\end{array}$} & \multirow[b]{2}{*}{ Reference } \\
\hline & & $\begin{array}{l}\text { No. of } \\
\text { Patients }\end{array}$ & Treatment, \% & Control, \% & $\begin{array}{l}\text { Follow-up } \\
\text { Interval, days }\end{array}$ & & \\
\hline ISAM & SK & 1,741 & 6.3 & 7.1 & 21 & 11 & 5 \\
\hline GISSI & SK & 11,712 & 10.7 & 13.0 & 21 & 18 & 6 \\
\hline ISIS-2 & SK & 17,187 & 9.1 & 11.8 & 35 & 23 & 8 \\
\hline ASSET & alteplase & 5,011 & 7.2 & 9.8 & 30 & 26 & 8 \\
\hline ECSG-5 & alteplase & 721 & 2.8 & 5.7 & 14 & $51^{\star}$ & 9 \\
\hline AIMS & anistreplase & 1,004 & 6.4 & 12.2 & 30 & 47 & 10 \\
\hline LATE & alteplase & 5,711 & 8.9 & 10.3 & 35 & 14 & 16 \\
\hline EMERAS $†$ & SK & 4,534 & 13.2 & 14.4 & 35 & 9 & 17 \\
\hline
\end{tabular}

SK indicates streptokinase; alteplase, single chain tissue-type plasminogen activator; anistreplase, anisoylated plasminogen streptokinase activator complex (APSAC).

$\star P=.06$, secondary end point.

†86\% of patients randomized 7 to 24 hours after onset of pain.

It should be noted that because of the variability in patient selection, adjunctive use of antithrombotic agents and mechanical interventions, these results are not suited for comparison of treatment related mortalities among trials.

which is sufficient to neutralize (in vitro) a standard dose of SK and to make repeated treatment with SK of uncertain efficacy. ${ }^{26}$ In some patients, such antibody titers can persist for several years. From a practical standpoint, once SK has been used, repeated thrombolytic treatment should be with TPA or urokinase rather than with SK or anistreplase.

TPA is a human protein produced by recombinant DNA technology. TPA is a poor enzyme in the absence of fibrin, which strikingly enhances the activation rate of plasminogen by at least 100 times. Activation of the fibrinolytic system thus seems to be triggered by and confined to fibrin. ${ }^{25}$ TPA has been produced in two forms: a single-chain preparation (alteplase) and a double-chain preparation (duteplase). Most studies have used alteplase.

Two dosage regimens of alteplase are currently in use. These are (1) $100 \mathrm{mg}$ IV over 3 hours $(10 \mathrm{mg}$ bolus, $50 \mathrm{mg}$ over the first hour, and $20 \mathrm{mg}$ over each of the next 2 hours) or, preferably, (2) as a weight-adjusted, accelerated ("front-loaded") regimen over 90 minutes ( $15 \mathrm{mg}$ bolus, $0.75 \mathrm{mg} / \mathrm{kg}$ over 30 minutes [not to exceed $50 \mathrm{mg}$ ], and $0.5 \mathrm{mg} / \mathrm{kg}$ over 60 minutes [not to exceed 35 $\mathrm{mg}]$ ). The total dose does not exceed $100 \mathrm{mg}$. Because of the clear survival benefit of the accelerated regimen over SK demonstrated in GUSTO (see below), the accelerated regimen is recommended.

Anistreplase is an equimolar complex between human Lys-plasminogen and SK in which the active center is blocked by reversible acylation with $p$-anisic acid. It was constructed with the aim of controlling the enzymatic activity of the plasmin(ogen)-SK complex. The usual therapeutic dose is $30 \mathrm{U}$ given as a slow IV injection over approximately 3 to 5 minutes. Anistreplase, like SK, is antigenic and can cause hypotension and significant allergic reactions in a small percentage of patients. A marked increase in SK antibody titer can persist. ${ }^{27}$

Single-chain urokinase-type plasminogen activator (scu-PA, prourokinase) is a human protein produced by recombinant DNA technology as saruplase. Urokinase is generated from prourokinase by cleavage of a single peptide bond. Currently, clinical-grade urokinase is obtained either from fetal kidney cell culture or from urine. At present, urokinase and prourokinase are not widely approved for the treatment of patients with AMI by IV administration. Both the single- and two-chain forms of urokinase plasminogen activator are nonantigenic.

\section{TABLE 2. Current Indications and Contraindications for Thrombolytic Therapy}

Current indications

Patients with chest pain consistent with the diagnosis of acute myocardial infarction and at least $0.1 \mathrm{~mm}$ of ST-segment elevation in at least two contiguous ECG leads in whom treatment can be initiated within 12 hours of pain onset, provided there are no contraindications to thrombolytic therapy

Expanded indications

Advanced age, controllable hypertension, a history of nontraumatic cardiopulmonary resuscitation, and left or right bundle branch block are no longer contraindications in patients with significant evidence for evolving myocardial infarction

\section{Contraindications}

History of a serious bleeding tendency; recent acute internal hemorrhages; major surgery, trauma, or delivery within 10 days; traumatic cardiopulmonary resuscitation; vascular puncture in a noncompressible site; and uncontrolled hypertension

Previous use of streptokinase or anistreplase is a contraindication for their repeated administration for at least 1 year because of their immunogenicity 


\title{
TABLE 3. Currently Used Regimens of Coronary Thrombolysis
}

\author{
Streptokinase and aspirin
}

Streptokinase (SK) 1.5 million U IV over 30 to 60 minutes, combined with acetylsalicylic acid (ASA) 160 to 325 mg daily started as soon as possible and continued indefinitely. The safety and efficacy of this regimen in terms of mortality reduction was established in ISIS-2, GISSI-2, and ISIS-3. It is associated with moderate efficacy for early coronary artery recanalization: about $55 \%$ patency at 90 minutes with a catch-up to about $80 \%$ at 3 hours. It is less efficient for mortality reduction in patients treated within the first 6 hours than accelerated alteplase and intravenous heparin as demonstrated by GUSTO.

\section{Alteplase and intravenous heparin}

The standard regimen of alteplase (tissue-type plasminogen activator; TPA) $100 \mathrm{mg}$ IV over 3 hours (10 mg bolus, $50 \mathrm{mg}$ over 1 hour, and $20 \mathrm{mg}$ over each of the following 2 hours) should, in view of the GUSTO results, probably be replaced by the accelerated regimen over 90 minutes $(15 \mathrm{mg}$ bolus, $0.75 \mathrm{mg} / \mathrm{kg}$ not exceeding $50 \mathrm{mg}$ over 30 minutes, and $0.5 \mathrm{mg} / \mathrm{kg} \mathrm{not}$ exceeding $35 \mathrm{mg}$ over the next hour). Both regimens include immediate 160 to $325 \mathrm{mg}$ ASA and immediate intravenous heparin (5000 U bolus and $1000 \mathrm{U}$ per hour, preferably monitored with activated partial thromboplastin time). In GUSTO, the accelerated regimen was associated with a statistically significant lower mortality than SK $(6.3 \%$ vs $7.3 \%, P=.001)$ but with a slightly higher incidence $(0.1 \%)$ of survival with disabling stroke. The high efficacy for early coronary artery recanalization $(75 \%$ to $85 \%$ patency at 90 minutes and persisting up to 5 days) requires conjunctive intravenous heparin. Alteplase is more expensive than SK.

\section{Anistreplase and aspirin}

Anistreplase (APSAC) 30 U IV given as a slow bolus over 3 to 5 minutes, in combination with aspirin $160 \mathrm{mg} / \mathrm{d}$. The comparative mortality reduction was similar to that with SKIASA in ISIS-3. The efficacy for early coronary artery recanalization is probably between that of SK and front-loaded alteplase.

\section{Selection of Regimen}

The GUSTO trial has demonstrated a significant overall survival benefit of accelerated TPA given with intravenous heparin over previous regimens, particularly SK with subcutaneous or with intravenous heparin (14\% mortality reduction with $95 \%$ confidence intervals of $6 \%$ to $21 \%$ ) and a consistent pattern of fewer complications, including allergic reactions, clinical indicators of left ventricular dysfunction, and arrhythmias. The survival benefit is largest in patients $<75$ years old, with anterior infarction, and $<4$ hours from onset of symptoms. No subgroups were identified in which TPA was significantly worse than SK but, possibly because of a lack of statistical power, no statistically significant benefit of TPA compared with SK was documented in patients $>75$ years old, in patients with small inferior infarcts, and in patients presenting $>4$ hours after the onset of symptoms. Therefore, if cost considerations become a limiting factor, TPA should be reserved primarily for the former subgroups and SK for the latter. If financial constraints do not permit the use of any thrombolytic agent, ASA should be administered as soon as possible.

\section{Comparative Clinical Trials of Thrombolytic Agents}

Comparative trials of SK and TPA (mostly the singlechain alteplase preparation) have shown a difference in efficacy for early coronary artery recanalization. ${ }^{28}$ Early patency, measured by coronary arteriography at approximately 90 minutes after the start of therapy, is approximately $22 \%$ with placebo, $53 \%$ with SK, and $75 \%$ with alteplase (and up to $85 \%$ with the accelerated regimen). ${ }^{29}$ The other thrombolytic agents have an efficacy for early recanalization that is probably intermediate between that of SK and alteplase. A catch-up phenomenon occurs with SK within 3 hours, however, so that patency of the infarct-related coronary artery with both SK and TPA is about $75 \%$ to $80 \%$ at 3 hours. ${ }^{30}$

The GISSI-2/International TPA/SK mortality study (20 891 patients) $)^{31,32}$ and the ISIS-3 trial (41 299 patients) ${ }^{33}$ were megatrials that compared SK and TPA (single-chain alteplase [100 $\mathrm{mg}$ IV over 3 hours] in the former and double-chain duteplase $[0.6 \mathrm{MU} / \mathrm{kg}$ IV over 4 hours] in the latter study). Delayed subcutaneous (SC) heparin or no heparin was used in most patients in both studies. Both trials showed no statistically significant difference in survival between SK and TPA. Several explanations have been proposed for the lack of apparent correlation in these studies between initial (90minute) patency of the infarct-related artery in patients receiving TPA and mortality. These include the possibility that long-term clinical benefit is due primarily not to early recanalization but rather to other mechanisms of greater importance, such as a reduction of blood viscosity or protective hypotension against cerebral bleeding with SK or an excess or intermittent reocclusion with TPA unprotected by IV heparin. A second hypothesis is that these trials did not routinely use adjunctive IV heparin with TPA, resulting in similar patency rates and mortality benefit with SK and TPA.

GUSTO (41 021 patients) $)^{34}$ compared the outcomes up to 30 days of four different regimens: (1) SK 1.5 million U IV over 60 minutes with 12500 U heparin SC every 12 hours begun 4 hours after the start of the SK infusion; (2) SK 1.5 million U over 60 minutes with concurrent IV heparin in a bolus dose of $5000 \mathrm{U}$ IV and $1000 \mathrm{U} / \mathrm{h}$ (a dose of $1200 \mathrm{U} / \mathrm{h}$ was recommended for patients weighing more than $80 \mathrm{~kg}$ ), with the dose adjusted to raise the activated partial thromboplastin time (aPTT) to between 60 and 85 seconds; (3) weightadjusted, accelerated ("front-loaded") TPA in a bolus dose of $15 \mathrm{mg}, 0.75 \mathrm{mg} / \mathrm{kg}$ body wt over a 30 -minute period, not to exceed $50 \mathrm{mg}$, and $0.5 \mathrm{mg} / \mathrm{kg}$, up to $35 \mathrm{mg}$, over the next 60 minutes with the same IV heparin regimen; and (4) a combination of SK (1 million U IV over 60 minutes) and weight-adjusted TPA $(1.0 \mathrm{mg} / \mathrm{kg}$ IV over 60 minutes, not to exceed $90 \mathrm{mg}$, with $10 \%$ given in a bolus dose) with simultaneous IV heparin. IV heparin was given for at least 48 hours. All patients received early ASA ( $\geq 160 \mathrm{mg}$ ) followed by 160 to 325 $\mathrm{mg} / \mathrm{d}$; IV atenolol was recommended if there were no contraindications.

The 30-day mortality and the rate of disabling stroke were as follows: (1) SK with delayed SC heparin, 7.2\% and $0.5 \%$; (2) SK with concurrent IV heparin, $7.4 \%$ and $0.5 \%$; (3) accelerated TPA with concurrent IV heparin, $6.3 \%$ and $0.6 \%$; and (4) combination of SK and TPA with IV heparin, $7.0 \%$ and $0.6 \%$. The 30 -day mortality 
in patients receiving accelerated TPA and IV heparin was $6.3 \%$, while the mortality of the combined groups of patients receiving SK with either SC or IV heparin was $7.3 \%$. This absolute difference of $1.0 \%$ is $14 \%$ of $7.3 \%$, the SK mortality. A combined end point of death or disabling stroke was also significantly lower in the accelerated TPA group than in the SK-only groups (6.9\% versus $7.8 \%, P=.006)$.

The need for heparin in patients treated with SK and ASA is uncertain on the basis of the GISSI-2/International study and ISIS-3.31-33 The results of GUSTO indicate that when SK is used, IV heparin does not convey benefit over SC heparin ${ }^{34}$ (see below). In GUSTO, there was a trend toward increased bleeding in patients treated with SK and IV heparin compared with patients treated with SK and SC heparin. On the other hand, IV heparin may be appropriate for high-risk patients with very poor left ventricular function, anterior or apical myocardial infarction, or with a high probability of mural thrombus. In GUSTO patients treated with TPA, the simultaneous administration of IV heparin with careful adjustment of the dose to achieve and maintain a therapeutic aPTT level resulted in the lowest 30 -day mortality $(6.3 \%)$, although the rate of disabling stroke was slightly increased to $0.6 \%$. The rate of nonfatal, disabling stroke was $0.5 \%$ for patients treated with SK with either SC or IV heparin. The difference $(0.1 \%)$ between the incidence of disabling stroke in surviving patients treated with SK and with TPA was not statistically significant.

A major finding of great significance in all clinical trials is the importance that patients receive the thrombolytic therapy as soon after the onset of symptoms as possible. In GUSTO, the mortality was $4.3 \%$ in patients receiving alteplase within 2 hours after the onset of symptoms, $5.5 \%$ for those treated 2 to 4 hours after the onset, and $8.9 \%$ in those treated 4 to 6 hours after the onset of symptoms. The mortality of patients treated with SK in the same time intervals was $5.4 \%, 6.7 \%$, and $9.3 \%$. This trend was also observed in the combination $\operatorname{arm} .^{34}$

\section{Concomitant Antithrombotic Treatment}

It appears that all thrombolytic agents induce both a prothrombotic state and activation of platelets. $6,35-40$ The prothrombotic state may be particularly relevant following therapy with TPA, which has a short half-life. The prothrombotic state following lytic therapy is only partially blocked by heparin. ${ }^{35,36}$ Whereas SK activates platelets, SK (but not TPA) appears to produce a plasmin-dependent inhibition of platelet function by a mechanism that does not involve the IIb/IIIa fibrinogen receptor. ${ }^{41}$ Thus, the induction of a systemic lytic state might favor the use of less fibrin-specific agents. One smaller trial suggested that lysis with SK was significantly faster and more complete with simultaneous IV heparin compared with placebo. ${ }^{42}$ In patients treated with SK in GUSTO, however, there did not appear to be a benefit of concomitant IV heparin (7.4\% 30-day mortality, $0.5 \%$ disabling stroke) compared with the results in patients treated with SK and concomitant delayed SC heparin (7.2\% 30-day mortality, $0.5 \%$ disabling stroke). ${ }^{34}$

\section{Acetylsalicylic Acid}

ISIS-2 ${ }^{11}$ demonstrated that early treatment with ASA $(160 \mathrm{mg} / \mathrm{d})$ reduced mortality by about $23 \%$, whether or not thrombolytic therapy with SK was used. The effects were comparable to those of SK alone, and the beneficial effects of the two drugs were roughly additive. In combination with SK, ASA was not associated with excess cerebral hemorrhage or bleeding requiring transfusion. Because of these results in ISIS-2, ASA has been used in virtually all subsequent clinical trials, and there has been no obvious excess bleeding, even when ASA is combined with TPA and IV heparin. The optimal dose of ASA in patients with AMI is uncertain. A dose of 160 $\mathrm{mg}$ in ISIS-2 was used as a compromise between the safety of a very low dose (30 to $50 \mathrm{mg}$ ) and the desire for a rapid effect on cyclooxygenase inhibition in patients with AMI, who may have significantly altered hemodynamic and thrombotic function. It would appear reasonable to have the patient chew and swallow $325 \mathrm{mg}$ regular ASA as soon as the diagnosis of AMI is established or highly likely and to have the patient take 75 to $325 \mathrm{mg} / \mathrm{d}$ thereafter. Slow-release or buffered forms of ASA should be avoided for the first dose of ASA. Some forms of ASA designed for the use of infants or children may be buffered and slowly absorbed.

\section{Heparin}

IV heparin in the absence of ASA is effective in significantly decreasing thrombosis and rethrombosis after thrombolytic therapy, ${ }^{37-39}$ particularly in those patients whose aPTT is greater than twofold control.6,39,40 Heparin therapy, however, is associated with an increase in bleeding complications, ${ }^{11,34}$ and therapy with IV heparin requires additional effort to maintain a therapeutic aPTT of 60 to 85 seconds. ${ }^{34}$

Several small trials (Bleich et al, ${ }^{37}$ HART, ${ }^{39}$ and $\mathrm{ECSG}^{40}$ ) randomized patients to receive either IV heparin or no heparin following TPA for AMI. Although these three trials had different designs and evaluated patients at different intervals, all found that in patients treated with TPA, IV heparin was associated with greater patency of the infarct-related artery than in patients not receiving heparin. In the Bleich study, ${ }^{37}$ ASA was not used; in the HART trial, $80 \mathrm{mg}$ ASA was used $^{39}$; and in the ECSG trial, a 250-mg IV loading dose of ASA was used followed by 75 to $125 \mathrm{mg}$ of oral ASA on alternate days. ${ }^{40}$ In ISIS- $3{ }^{33}$ and in GISSI- 2 and its extension, ${ }^{31,32}$ delayed SC heparin added to ASA significantly reduced reinfarction but appeared to be associated with a greater incidence of cerebral and other major noncerebral bleeding requiring blood transfusion but with no decrease in the 5-week or longer-term mortality. ${ }^{31-33}$ This was statistically significant with duteplase in ISIS-3 but not with alteplase in GISSI-2.

In GUSTO, the combination of SK and SC heparin (12 $500 \mathrm{U}$ beginning 4 hours after the start of SK) was associated with a 30 -day mortality of $7.2 \%$ and $0.5 \%$ incidence of disabling stroke. ${ }^{34}$ When IV heparin was administered immediately ( $5000 \mathrm{U}$ bolus, followed by an infusion of $1000 \mathrm{U} / \mathrm{h}$, with aPTT adjusted to 60 to 85 seconds) together with SK, the 30-day mortality was $7.4 \%$ and the incidence of disabling stroke $0.6 \%$. In patients given accelerated TPA and IV heparin, the 30 -day mortality was $6.3 \%$ and the rate of disabling 
stroke $0.6 \%$. In patients treated with the combination of SK plus TPA and IV heparin, the 30-day mortality was $7.0 \%$ and the rate of disabling stroke was $0.6 \%$. In patients treated with SK in the Dutch APRICOT Study, ${ }^{43}$ ASA was superior to warfarin in terms of both angiographic and clinical outcome when oral warfarin was added when IV heparin was discontinued.

There is a need for studies to identify which patients treated with SK should also receive SC heparin. ${ }^{44}$ At present, there are no clear data indicating that patients treated with SK and ASA benefit from the addition of either SC or IV heparin.

When thrombolytic therapy is carried out with TPA, it is recommended that IV heparin should be administered concurrently as a bolus of $5000 \mathrm{U}$ followed by an infusion rate of $1000 \mathrm{U} / \mathrm{h}(1200 \mathrm{U} / \mathrm{h}$ if body weight is $>80 \mathrm{~kg}$ ) and that aPTT be measured at 6 hours and the dose of heparin adjusted to maintain the aPTT 1.5 to 2 times the control value or 60 to 85 seconds. ${ }^{34}$

\section{Warfarin}

The use of warfarin has not been adequately evaluated in the acute phase of AMI in the thrombolytic era. In general, its use has been reserved for patients with a high thromboembolic risk who require chronic anticoagulant therapy, such as patients with a large anterior myocardial infarction, mural thrombus, atrial fibrillation, and/or marked left ventricular dysfunction.

\section{Newer Antithrombotic Regimens}

Hirudin totally blocks the activity of thrombin, which is generated during thrombolysis. Hirudin appears to be very effective in the prevention of thrombosis, but this effect is variable, 45 and further clinical studies of the use of hirudin and Hirulog, a synthetic hirudin-like polypeptide, are under way. 46,47

Fibrinogen receptor antagonists block the receptor that binds platelets to fibrinogen and also platelets to each other. They inhibit the formation of platelet-rich thrombi ${ }^{48}$ and are also undergoing clinical evaluation.

Thromboxane antagonists and thromboxane synthetase inhibitors affect the ASA-insensitive mechanisms of platelet aggregation. Both together may be more effective than either alone, as demonstrated in experimental animals. ${ }^{49}$

Monoclonal antibodies against plasminogen activator inhibitor experimentally accelerate physiological thrombolysis and may be useful prophylactically. ${ }^{50,51}$

\section{Bleeding}

The incidence of bleeding is increased in patients with suspected AMI treated with thrombolytic therapy compared with conservative management. ${ }^{52,53}$ The risk of extracranial bleeding is virtually the same regardless of the thrombolytic agent when they are used within the approved dose ranges. ${ }^{33}$ The rate of bleeding is $<5 \%$ in reports with noninvasive studies ${ }^{9-15,53,54}$ but $>30 \%$ in reports of studies in which invasive studies such as cardiac catheterization are used to assess vessel patency.55-61 The risk of extracranial bleeding is also increased by older age, smaller size, and female sex. ${ }^{53}$

Intracranial bleeding is the most serious complication of thrombolytic therapy. It has been reported to occur in between $0.2 \%$ and $1.6 \%$ of subjects in large trials. ${ }^{11-15}$ In addition to differences related to the thrombolytic agent used, some of the reported differences may be related to patient selection, the diagnostic criteria used, and underreporting. In most larger trials, the incidence of major bleeding has been more than three times greater and the rate of intracranial bleeding two to four times greater in patients receiving thrombolytic therapy. ${ }^{8-14,32,53,61}$ In most studies, the incidence of intracranial hemorrhage has varied between $0.3 \%$ and $1.4 \%$, for an absolute increase of about $0.2 \%$ to $1.0 \% .^{53}$ In general, the incidence of intracranial hemorrhage has been slightly higher in patients treated with TPA or anistreplase than in patients treated with SK. ${ }^{31-33,52,53}$ The risk of intracranial hemorrhage appears to be increased in patients older than about 65 years, in patients with uncontrolled systemic arterial hypertension (systolic pressure $>150 \mathrm{~mm} \mathrm{Hg}$ or diastolic pressure $>100 \mathrm{~mm} \mathrm{Hg}$ ), and in patients with a history of prior hemorrhagic stroke. In some studies, anterior infarction, female sex, and poor hemodynamic status have been associated with a higher incidence of hemorrhagic stroke. .52

The increase in hemorrhagic stroke associated with thrombolytic therapy is balanced by a lower incidence of thrombotic and embolic stroke. As a result, thrombolytic therapy is probably associated with only a very slightly increased risk overall of cerebrovascular accident. ${ }^{62,63}$ Even without the decrease in thrombotic and embolic stroke, the very small increase in fatal or disabling stroke associated with thrombolytic therapy is much less than the very significant decrease in mortality from myocardial infarction associated with such therapy.

\section{Coronary Angioplasty and Coronary Artery Surgery}

Since intracoronary thrombolysis has been replaced by the IV route, coronary angiography is no longer performed routinely in patients with evolving myocardial infarction. There is no pressing need for coronary angiography in patients experiencing an uncomplicated course. Nevertheless, there are some advantages to early angiography. Important information that has prognostic value regarding the coronary circulation and the detection of high-risk situations may be obtained. ${ }^{64}$ Failure of thrombolysis, left main coronary artery stenosis, three-vessel disease, one-vessel disease, or minimal intracoronary changes can be differentiated. Such knowledge may help to establish a rationale for continuing medical treatment or for undertaking PTCA or CABG. Patients who have reocclusion after initially successful reperfusion have increased mortality and/or deterioration of left ventricular function. ${ }^{38,65}$ Unfortunately, however, no simple, dependable predictors of reocclusion are available, and no absolutely reliable pharmacological strategies exist to prevent it.66 What is clear from a comparison of the SAVE patients recruited in Canada versus those recruited in the United States is that more aggressive investigation and intervention in the United States did not result in any difference in mortality. 67

Early experiences with intracoronary thrombolysis and acute angiography 68,69 suggested that immediate PTCA would improve reperfusion by opening of the vessel in failed thrombolysis and by lessening of the residual stenosis in those who have achieved successful 
recanalization. It was hoped that immediate angioplasty would reduce the rate of reocclusions, recurrent angina pectoris, malignant arrhythmias, and mortality, as well as improving myocardial performance. Later studies, however, have not shown this to be the case. ${ }^{55,57,69-71}$

Diagnostic difficulties may arise because residual thrombus, which may dissolve later spontaneously, may suggest a higher-grade stenosis on coronary arteriography than actually exists. ${ }^{72-74}$ Also, the intracoronary PTCA balloon can destabilize the ruptured plaque, activate the vessel surface and platelets, or cause a rethrombosis or a severe dissection..$^{55,70}$ Furthermore, PTCA under these circumstances requires a very experienced physician who may not always be available on a 24-hour basis. The usefulness of atherectomy catheters, lasers, rotational atherectomy, or stents has not been proven in randomized studies for these purposes. Thus, it is advisable that therapy be individualized with respect to PTCA, depending on the clinical situation. $6,20-22,38,75-77$

\section{Direct PTCA}

Direct or primary coronary angioplasty was introduced by Hartzler et al. ${ }^{19,78}$ It has the advantage of a high rate of reperfusion ( $>90 \%$ versus $75 \%$ with IV thrombolysis). It has been used primarily in patients presenting early after the onset of symptoms, especially in the elderly and in those with signs of large infarctions, risk of cardiac shock, bleeding abnormalities, malignant hypertension, those who have experienced prior CABG, those who have had recent major surgery, and in patients who have experienced recent strokes or accidents. ${ }^{65}$ Coronary angioplasty may lead to trauma of the vessel and downstream embolization of thrombotic material and may cause damage to the myocardium and malignant arrhythmias by the sudden reperfusion. During the procedure, a small dose of 50000 to $500000 \mathrm{U}$ of SK or urokinase may be injected into the culprit coronary vessel to lyse residual thrombi with little systemic effect.

Several randomized clinical trials have shown that in the hands of experienced physicians, direct PTCA has been successfully accomplished with mortality and functional results comparable, or at times even superior, to that seen in patients receiving thrombolytic therapy. $22-24,79$ Direct PTCA clearly is limited by the immediate availability of costly facilities and staffing of catheterization laboratories that permit immediate access to a patient presenting early with myocardial infarction. As a result, it is currently performed in only a minority of cases and primarily in patients in whom thrombolysis is felt to be contraindicated.

\section{Rescue PTCA}

In patients with severe left ventricular failure or signs of cardiogenic shock despite preceding IV thrombolytic therapy, the mechanical opening of the occluding vessel and dilatation of the underlying coronary stenosis may lead to significant improvement. ${ }^{20-24,65,77-80}$ The success rate is less than with routine PTCA, and patency can be achieved in only $70 \%$ to, at most, $90 \%$ of cases. Rescue PTCA is indicated in the early phase of cardiogenic shock and in patients in whom pharmacological thrombolysis has failed and in patients demonstrating continuing chest pain. In a subset of patients with cardiogenic shock, in-hospital mortality with open vessels was ap- proximately $25 \%$ compared with $75 \%$ when the vessel remained occluded. $.55,80$ Despite the acute opening of the infarct-related artery and the supply of oxygenated blood to the previously ischemic myocardium, abrupt reperfusion may produce problems. ${ }^{50}$ Large randomized trials are lacking. Because prognosis is extremely poor under the above circumstances, emergency PTCA, if available, should be attempted when the vessel is occluded. $21,80,81$

The role of rescue angioplasty late in the hospitalization period in a patient who is otherwise progressing satisfactorily is controversial. Some suggest that the open-artery hypothesis requires that rescue angioplasty be attempted whenever a closed vessel is encountered. The late results from such attempts have not overwhelmingly documented this benefit. Consequently, it does not seem desirable at this stage of our knowledge to recommend rescue angioplasty for the asymptomatic patient recovering from myocardial infarction, if for no other reason than that it would require routine cardiac catheterization of all patients to discover this particular subset.

\section{Immediate PTCA}

The observations gained by early angiography in evolving myocardial infarction showing residual highgrade stenosis in many cases lead to the concept of aggressive immediate intervention by PTCA following thrombolytic therapy. ${ }^{68,69}$ It was postulated that diminishing the stenosis would result in better perfusion of the myocardium, improvement of the left ventricular function, and reduction of postinfarction angina, as well as fewer malignant arrhythmias. Several randomized clinical trials have not validated this assumption. ${ }^{55,57,70,71}$ The rate of complications, including abrupt artery closure, reinfarction, and death, was higher in those receiving routine immediate angioplasty than in those who were treated more conservatively. Immediate PTCA is therefore not recommended as a routine procedure.

\section{Elective PTCA}

Delayed or elective angioplasty during the hospital recovery period of an infarct may be considered if recurrent anginal symptoms, laboratory evidence of continuing ischemia, or malignant arrhythmias are recorded. $5,18,21,65,72,73,76,77$ Noninvasive tests of continuing ischemia are not totally reliable and at times can be difficult to interpret. In general, symptom-limited exercise tests carried out with thallium or technetium sestamibi imaging have been shown to have a reasonable reliability, although it is recognized that at times patients may not be able to exercise adequately. Under these circumstances, dipyridamole thallium or dipyridamole sestamibi tests have proved useful. In some centers, exercise or dobutamine wall-motion studies using either echocardiography or radionuclide ventriculography are used. Nevertheless, separation of stunned from hibernating or necrotic from still viable myocardium may be difficult. Advanced techniques such as positron emission tomography are not in widespread use.

Should noninvasive studies show continuing ischemia, or if the patient demonstrates postinfarction angina, angiography should be carried out promptly with a view to performing PTCA in lesions amenable to this technique. The TIMI-2B study found that a number of 
patients in the conservative arm developed recurrent ischemia during the hospital phase and in the following weeks. ${ }^{57,59}$ The need for catheterization reached $24 \%$ among these patients, and PTCA was carried out in $17 \%$. Nevertheless, there is no need for routine cardiac catheterization in patients following uncomplicated AMI with a view toward PTCA being carried out electively in the absence of postinfarction ischemia. A plan of watchful waiting is generally recommended. $5,6,14,68,69,75,79-83$

\section{Coronary Artery Bypass Graft Surgery}

Emergency operation within the first 6 hours for evolving myocardial infarction has been performed by several groups. ${ }^{84-87}$ Improved survival and salvage of myocardium were shown. In a small series of patients with cardiogenic shock, the results were significantly better than with conservative treatment. ${ }^{87}$ One of the major roles for CABG in AMI is in the patient with cardiogenic shock. Such patients are probably best taken directly to the cardiac catheterization laboratory and the anatomy defined. If PTCA, with or without associated thrombolytic therapy, is deemed to be not feasible on the basis of the coronary anatomy, an intra-aortic balloon pump should be inserted and immediate emergency bypass surgery carried out.

The routine use of $C A B G$ as a therapeutic alternative to either direct PTCA or IV thrombolysis, however, is generally felt to be impractical. Surgical teams are not immediately available, and the logistics of carrying out acute coronary angiography and subsequent bypass surgery within the early window period of maximum myocardial salvage is an enormous burden even in large, dedicated centers.

In patients who develop papillary-muscle rupture, a ventricular septal defect, or subacute pericardial tamponade from myocardial rupture, early or immediate $\mathrm{CABG}$ is needed. When severe pump failure or cardiogenic shock is established, the prognosis is poor. Intraaortic balloon counterpulsation or other assist devices may help to bridge the interval until surgical revascularization. ${ }^{29}$ In the TIMI-2B study, $11 \%$ of all patients underwent CABGwithin the first 6 weeks. ${ }^{69}$

In patients with left main stenosis or severe two- or three-vessel disease unsuitable for PTCA who exhibit continuing ischemia, early surgery should be considered. Often this may be performed before hospital discharge. ${ }^{18-22,79-84}$ There still is controversy, however, concerning the optimal time of operation, that is, whether to perform surgery during the very early period of 2 to 5 days or to delay for 1 to 3 weeks. In general, when bypass surgery is done during the first day, the results have been satisfactory; however, when 3 or 4 days have passed, the results tend to be less satisfactory. By the time 2 to 3 weeks have passed, however, the patient's condition is usually well stabilized, and surgical mortality is quite low. Precise recommendations on the role of bypass surgery clearly have to be individualized.

\section{Risk Stratification and Predischarge Evaluation}

Predischarge evaluation and risk stratification of most patients following thrombolytic therapy for AMI are recommended to determine whether or not additional medical therapy or interventions (PTCA, surgery) are warranted, to determine activities that should be recommended or discouraged, and to assess prognosis.

The mortality following myocardial infarction is related to many factors, including patient characteristics existing before the infarction. These include advanced age, a history of myocardial infarction or angina pectoris, systemic arterial hypertension, diabetes mellitus, and female sex. ${ }^{88}$ Cigarette smoking is associated with an increased risk in patients who continue to smoke.

The mortality following myocardial infarction is also related to patient characteristics during hospitalization. ${ }^{88-93}$ These factors include subjective or objective evidence of recurrent myocardial ischemia, important left ventricular dysfunction requiring the use of digoxin and/or diuretics, and electrical instability, including frequent premature ventricular depolarizations, ventricular tachycardia, advanced heart block, and atrial tachyarrhythmias. 94

Most of the studies of the usefulness of noninvasive testing to identify patients at high risk for future cardiac events after myocardial infarction were performed on patients who did not receive thrombolytic therapy. While some studies have suggested that the positive and negative predictive value of some noninvasive tests may be somewhat less in patients treated with lytic therapy, ${ }^{95-104}$ other studies have confirmed the strong relation between prognosis and status of such patients at the time of discharge. $93,105,106$

Risk stratification by noninvasive testing performed before discharge from the hospital is of particular value in patients who do not appear to be at high risk on the basis of clinical characteristics. The three major determinations of prognosis in patients after recovery from myocardial infarction are evidence of myocardial ischemia, ventricular function, and ventricular ectopy. ${ }^{88-94,106}$ Evidence of myocardial ischemia may be obtained by electrocardiography, myocardial perfusion imaging with ${ }^{201} \mathrm{Tl}$ or Tc sestamibi, ${ }^{105,107,108}$ or the development of wall motion abnormalities on echocardiography ${ }^{109-111}$ or radionuclide ventriculography. These tests can also be used during stress produced by exercise, by pharmacological stress produced by the administration of a coronary vasodilator (dipyridamole or adenosine) or a positive inotrope (dobutamine), or by cardiac pacing. Stress thallium imaging is more specific and more sensitive for the detection of myocardial ischemia than bicycle ergometer or treadmill exercise electrocardiography, although it is considerably more expensive. ${ }^{108}$

Diminished left ventricular systolic function, which can be identified by an ejection fraction of $\leq 40 \%$ on a radionuclide ventriculogram or echocardiogram, is a very powerful prognostic factor in patients following myocardial infarction. ${ }^{88-94}$ Patients who increase their left ventricular ejection fraction during exercise have a better prognosis than those whose ejection fraction remains the same or decreases. ${ }^{112}$ The prognosis is particularly poor for patients judged to be unfit for a predischarge exercise test. ${ }^{88,91-94,106}$

Episodes of ventricular tachycardia or ventricular fibrillation that occur more than 24 hours after myocardial infarction identify patients at increased mortality risk. ${ }^{44}$ Increased risk is also associated with 10 or more premature ventricular depolarizations per hour or diminished heart rate variability on a 24 -hour ambulatory ECG, late potentials on a signal-averaged ECG, exer- 
cise-induced ventricular arrhythmias, or an abnormal electrophysiological study.

The extent and degree of coronary artery disease are also important determinants of subsequent mortality. ${ }^{88,93,105,106}$ The extent of coronary artery disease and patency of the infarct-related artery are best evaluated by cardiac catheterization with coronary arteriography. It is important to note that the presence of thrombus can hinder the accurate assessment of the amount of underlying coronary atherosclerosis.

Patients who have received thrombolytic therapy in general have less severe coronary artery disease and better left ventricular function than patients who do not receive such therapy. This is reflected in a lower major cardiac event rate for several years after thrombolytic therapy. The diagnostic accuracy and prognostic value of noninvasive testing appears to be less in patients who have received thrombolytic therapy, perhaps related to the less severe coronary artery disease and better left ventricular function and possibly also to the use of inadequate stress during the test or to the use of coronary angioplasty or $\mathrm{CABG}$ as end points in some clinical trials.

\section{A Systematic Approach}

In general, patients who have a hospital course that is uncomplicated by recurrent angina, refractory heart failure, cardiac arrest, or sustained ventricular tachycardia and who have a left ventricular ejection fraction $\geq 40 \%$ should have an exercise stress ECG test using either a bicycle ergometer (steps of 10 or $20 \mathrm{~W} / \mathrm{min}$ ) or a treadmill (modified Bruce protocol or similar protocol). Such tests can be symptom limited, although the threshold to stop exercise should be lower than in more stable situations. ${ }^{96}$ Exercise radionuclide scintigraphy, which has greater diagnostic value, can also be used, but it is more expensive. It is especially useful in patients whose resting ECG has changes that limit the usefulness of the exercise ECG. In experienced hands, stress echocardiography using exercise or IV dobutamine is also useful in the detection of wall motion abnormalities due to myocardial ischemia. Patients who have objective evidence of myocardial ischemia on noninvasive testing are generally referred for cardiac catheterization and coronary arteriography.

Patients who have an uncomplicated course but have a left ventricular ejection fraction $<40 \%$ but $>20 \%$ may be considered for referral to cardiac catheterization and coronary arteriography. In addition, patients whose hospital course is complicated by recurrent angina, refractory heart failure, or sustained ventricular tachycardia are often referred for cardiac catheterization. ${ }^{113,114}$ Patients whose hospital course is complicated by documented ventricular tachycardia, cardiac arrest, or sustained ventricular tachycardia occurring more than 48 hours after the presumed onset of their infarction should be considered for electrophysiological study. ${ }^{114}$ Electrophysiological study should also be considered for patients with an uncomplicated course who have a left ventricular ejection fraction of $\leq 40 \%$ together with abnormal late potentials on a signal-averaged ECG, particularly if the 24-hour ambulatory ECG is also abnormal.

The determination of which noninvasive test to use depends on the local facilities and experience, the relative cost-effectiveness of the test in different subsets of patients, and the judgment of the physician.

In general, most studies have supported the selective use of cardiac catheterization and coronary arteriography rather than its routine use after thrombolytic therapy. $55,59,61,93,113,114$ In patients who have had thrombolytic therapy, early cardiac catheterization is appropriate in patients with persistent or recurrent pain due to myocardial ischemia, cardiogenic shock ${ }^{81}$ or severe pump failure, or mechanical complications such as severe mitral regurgitation or ventricular septal defect. Later in the hospital course, cardiac catheterization may be indicated if the patient has recurrent ischemic pain, persistent heart failure despite intensive medical therapy, or recurrent ventricular tachycardia or fibrillation despite intensive antiarrhythmic therapy. ${ }^{114}$ Predischarge cardiac catheterization and coronary arteriography may be indicated for patients with postinfarction angina pectoris, objective evidence of myocardial ischemia on noninvasive testing, or left ventricular ejection fraction $\leq 40 \% .^{114}$

Patients who have cardiac catheterization and coronary arteriography may be considered for myocardial revascularization by coronary angioplasty or surgical revascularization, depending on the individual patient characteristics and coronary anatomy and the local experience with these procedures. Recent studies indicate that positron emission tomography and myocardial scintigraphy with ${ }^{201} \mathrm{Tl}$ or other perfusion agents may help to assess myocardial viability and to detect patients in whom surgical revascularization or PTCA might improve left ventricular function. ${ }^{103}$

\section{Future Research}

Since GUSTO ${ }^{35}$ demonstrated an absolute $1 \%$ (relative $14 \%$ ) reduction in mortality in patients receiving accelerated TPA plus IV heparin compared with SK with both SC and IV heparin, it is likely that future studies will include the effects of SK regimens with a higher dose given during the first 30 minutes.

The role of anticoagulation remains an enigma. As noted previously, it is not clear that there is an additional benefit from the use of heparin when SK with ASA is administered. When the results of GISSI II, ISIS III, and GUSTO are combined, there does not appear to be an advantage when heparin is added to SK plus ASA. Accordingly, it is not clear at this time that heparin is necessary in patients treated with SK and ASA. From the results in GUSTO, however, it is clear that in patients treated with SK, SC rather than IV heparin can be used in routine cases.

It is not certain whether the greater benefits observed in GUSTO in the TPA plus concurrent IV heparin arm were primarily the result of the use of IV rather than SC heparin or the use of TPA in an accelerated regimen. While it would be desirable to know whether or not there is any difference between SC heparin compared with IV heparin in patients receiving accelerated TPA, this may never be studied, since attention is now being focused on newer anticoagulant drugs.

Heparin combines inadequately with fibrin-bound thrombin to inhibit subsequent thrombin activity. Drugs like hirudin and Hirulog are far more effective in accomplishing this. Maintenance of infarct-related artery patency after recanalization during the time when infarc- 
tion would normally evolve is essential to maximize benefit from thrombolytic therapy. Newer agents are being evaluated for this purpose. These include platelet antibodies and receptor antagonists, the newer antithrombin drugs that better inhibit fibrin-bound thrombin activity, white blood cell inhibitors, and complement inhibitors. Future research is needed to define the appropriate anticoagulant regimen that patients undergoing thrombolytic therapy should receive, including the drug, the manner of administration, and the duration of therapy.

Recent clinical trials comparing primary angioplasty with thrombolytic therapy have stimulated interest in the potential expanded role of primary angioplasty as a therapeutic alternative to initial thrombolysis despite the logistic difficulties. The role of angioplasty in patients in whom thrombolytic agents are indicated and can be used has yet to be fully determined, and it is likely that we will see larger clinical trials exploring this comparison. Furthermore, the role of angioplasty in the management of cardiogenic shock, in the elderly, and in patients who have had prior CABG is likely to be intensively studied, since thrombolytic therapy either is relatively less effective or is associated with a higherthan-average risk in these patients.

Relatively little is known regarding the interrelations between thrombolytic therapy and other pharmacological therapy that many patients receive. Our knowledge concerning the interactions of various thrombolytic agents with drugs such as nitroglycerin, $\beta$-blockers, calcium channel blockers, magnesium, angiotensin-converting enzyme inhibitors, lipid-lowering drugs, and ASA is small. Further research is needed on the relative potential synergism or interference that may occur. One cannot assume that mortality and morbidity data generated before the advent of coronary thrombolysis are applicable to the postthrombolytic era.

The ability to judge whether or not reperfusion has taken place without performance of coronary arteriography has been of interest for over a decade. The use of either ST-segment elevation, early peaking of serum creatine kinase levels, or the disappearance of chest pain have all proved disappointing. Although these criteria are reasonably sensitive, they lack adequate specificity. More recently, creatine kinase isoform analysis and continuous 12-lead ST-segment monitoring have been shown to be relatively effective, but these are costly, time-consuming, and not widely available. Continuing research to develop improved noninvasive techniques of identifying reperfusion can be anticipated.

Thrombolytic therapy is generally not applied to patients who have coexisting diseases that are likely to significantly shorten survival. Patients with other coexisting life-threatening diseases such as cancer are often not offered thrombolysis, although they may be considered potential candidates for angioplasty. The objections to thrombolysis in these cases are often ill defined but are generally centered around cost-effectiveness. More research is desirable to define the role of thrombolysis in the presence of other coexisting illnesses.

The benefits of thrombolytic therapy are now well established, and the trend toward decreased mortality can be demonstrated as early as 24 hours after the onset of therapy in some studies. The mechanism by which thrombolytic therapy improves survival, however, is not totally understood. In part, this reflects the lack of a large database on the causes of death within the first 24 hours in patients treated with thrombolytic therapy compared with controls. Additionally, autopsy evidence is desirable; in addition, future studies of adjunctive measures to improve early mortality should also address how they alter the mechanism of death.

The characteristics that identify the patient who is likely to fail thrombolytic therapy are not well established, and research is needed to identify factors that predict whether or not recanalization will occur. Until it is understood why recanalization does not occur in some patients, it will be difficult to design measures to increase recanalization rates with either thrombolytic agents or other techniques.

Virtually all clinical trials support the concept that the earlier thrombolytic therapy is undertaken, the more likely a better survival and a lesser morbidity. The possibility of relatively early therapy for the majority of patients was well demonstrated in the GUSTO trial, in which, among more than 40000 randomized patients, the median time from the onset of chest pain to randomization was 2 hours and the median time to the institution of thrombolytic therapy was 2.8 hours. ${ }^{34}$ These relatively small time intervals were, in part, the reflection of intense efforts by the investigators and their nurse coordinators. Future research is desirable to identify the measures that hospitals, physicians, and patients need to undertake to ensure that what was accomplished in this megatrial can be widely applied and improved upon. The goal should be to initiate thrombolytic therapy within 60 minutes of the onset of symptoms and within 30 minutes of the patient's reaching an emergency room.

\section{Appendix \\ Members of the Task Force on Myocardial Reperfusion}

Robert C. Schlant, MD (Chairman); Robert A. O'Rourke, MD(ex officio); D. Collen, MD, PhD; J. Ward Kennedy, MD; Emilio Kuschnir, MD; Juergen Meyer, MD; Rodolfo Paoletti, MD; Bertram Pitt, MD; Elliot Rapaport, MD; Morie Sekiguchi, MD; Maarten L. Simoons, MD; and Peter Sleight, MD.

\section{References}

1. Horie T, Sekiguchi M, Hirosawa K. Coronary thrombosis in pathogenesis of acute myocardial infarction: histopathological study of coronary arteries in 108 necropsied cases using serial section. Br Heart J. 1978;40:153-161.

2. Falk E. Plaque rupture with severe pre-existing stenosis precipitating coronary thrombosis: characteristics of coronary atherosclerotic plaques underlying fatal occlusive thrombi. Br Heart $\mathrm{J}$. 1983;50:127-134.

3. Davies MJ, Thomas AC. Plaque fissuring: the cause of acute myocardial infarction, sudden ischaemic death, and crescendo angina. Br Heart J. 1985;53:363-373.

4. DeWood MA, Spores J, Notske R, Mouser LT, Burroughs R, Golden MS, Lang HT. Prevalence of total coronary occlusion during the early hours of transmural myocardial infarction. $N E n g l$ J Med. 1980;303:897-902.

5. Rentrop P, Blanke H, Karsch KR, Kaiser H, Köstering H, Leitz K. Selective intracoronary thrombolysis in acute myocardial infarction and unstable angina pectoris. Circulation. 1981;63: 307-317.

6. Julian D, Kübler W, Norris RM, Swan HJC, Collen D, Verstraete M, eds. Thrombolysis in Cardiovascular Disease. New York, NY: Marcel Dekker Inc; 1989. 
7. Braunwald E. Myocardial reperfusion, limitation of infarct size, reduction of left ventricular dysfunction, and improved survival: should the paradigm be expanded? Circulation. 1989;79:441-444.

8. The ISAM Study Group. A prospective trial of intravenous streptokinase in acute myocardial infarction (ISAM): mortality, morbidity, and infarct size at 21 days. $N$ Engl J Med. 1986;314: 1465-1471.

9. Gruppo Italiano per lo Studio della Streptochinasi nell'Infarto Miocardico (GISSI). Effectiveness of intravenous thrombolytic treatment in acute myocardial infarction. Lancet. 1986;1:397-402.

10. Gruppo Italiano per lo Studio della Streptochinasi nell'Infarto Miocardico (GISSI). Long-term effects of intravenous thrombolysis in acute myocardial infarction: final report of the GISSI study. Lancet. 1987;2:871-874.

11. ISIS-2 (Second International Study of Infarct Survival) Collaborative Group. Randomized trial of intravenous streptokinase, oral aspirin, both or neither among 17,187 cases of suspected acute myocardial infarction: ISIS-2. Lancet. 1988;2:349-360.

12. Wilcox RG, von der Lippe G, Olsson CG, Jensen G, Skene AM, Hampton JR. Trial of tissue plasminogen activator for mortality reduction in acute myocardial infarction: Anglo-Scandinavian Study of Early Thrombolysis (ASSET). Lancet. 1988;2:525-530.

13. Van de Werf F, Arnold AE. Intravenous tissue plasminogen activator and size of infarct, left ventricular function, and survival in acute myocardial infarction. Br Med J. 1988;297:1374-1379.

14. AIMS Trial Study Group. Effect of intravenous APSAC on mortality after acute myocardial infarction: preliminary report of a placebo-controlled clinical trial. Lancet. 1988;1:545-549.

15. AIMS Trial Study Group. Long-term effects of intravenous anistreplase in acute myocardial infarction: final report of the AIMS study. Lancet. 1990;335:427-431.

16. LATE Study Group. Late Assessment of Thrombolytic Efficacy (LATE) study with alteplase 6-24 hours after onset of acute myocardial infarction. Lancet. 1993;342:759-766.

17. EMERAS (Estudio Multicéntrico Estreptoquinasa Repúblicas de América del Sur) Collaborative Group. Randomised trial of late thrombolysis in patients with suspected acute myocardial infarction. Lancet. 1993;342:767-772.

18. Norris RM. An overview of trials establishing that thrombolytic therapy improves outcome in patients with acute myocardial infarction. Coron Artery Dis. 1992;3:96-102.

19. Hartzler GO, Rutherford BD, McConahay DR, Johnson WL Jr, McCallister BD, Gura GM Jr, Conn RC, Crockett JE. Percutaneous transluminal coronary angioplasty with and without thrombolytic therapy for treatment of acute myocardial infarction. Am Heart J. 1983;106:965-973.

20. Meyer J, Merx W, Dörr R, Lambertz H, Bethge C, Effert S. Successful treatment of acute myocardial infarction shock by combined percutaneous transluminal coronary recanalization (PTCR) and percutaneous transluminal coronary angioplasty (PTCA). Am Heart J. 1982;103:132-134.

21. O'Neill WW, Timmis GC, Bourdillon PD, Lai P, Ganghadarhan V, Walton J Jr, Ramos R, Laufer N, Gordon S, Schork MA, Pitt B. A prospective randomized clinical trial of intracoronary streptokinase versus coronary angioplasty for acute myocardial infarction. N Engl J Med. 1986;314:812-818.

22. Grines CL, Browne KF, Marco J, Rothbaum D, Stone GW, O'Keefe J, Overlie P, Donohue B, Chelliah N, Timmis GC, Vlietstra RE, Strzelecki M, Puchrowicz-Ochocki S, O’Neill WW. A comparison of immediate angioplasty with thrombolytic therapy for acute myocardial infarction. N Engl J Med. 1993;328:673-679.

23. Zijlstra F, de Boer MJ, Hoorntje JC, Reiffers S, Reiber JH, Suryapranata H. A comparison of immediate coronary angioplasty with intravenous streptokinase in acute myocardial infarction. N Engl J Med. 1993;328:680-684.

24. Gibbons RJ, Holmes DR, Reeder GS, Bailey KR, Hopfenspirger $\mathrm{MR}$, Gersh BJ. Immediate angioplasty compared with the administration of a thrombolytic agent followed by conservative treatment for myocardial infarction. $N$ Engl J Med. 1993;328: 685-691.

25. Collen D, Lijnen HR. Basic and clinical aspects of fibrinolysis and thrombolysis. Blood. 1991;78:3114-3124.

26. Goa KL, Henwood JM, Stolz JF, Langley MS, Clissold SP. Intravenous streptokinase: a reappraisal of its therapeutic use in acute myocardial infarction. Drugs. 1990;39:693-719.

27. Monk JP, Heel RC. Anisoylated plasminogen streptokinase activator complex (APSAC): a review of its mechanism of action, clinical pharmacology and therapeutic use in acute myocardial infarction. Drugs. 1987;34:25-49.
28. Chesebro JH, Knatterud G, Braunwald E. Thrombolytic therapy. N Engl J Med. 1988;319:1544-1545. Correspondence.

29. Collen D. Coronary thrombolysis: streptokinase or recombinant tissue-type plasminogen activator? Ann Intern Med. 1990;112. 529-538.

30. The GUSTO Angiographic Investigators. The effects of tissue plasminogen activator, streptokinase, or both on coronary-artery patency, ventricular function, and survival after acute myocardial infarction. N Engl J Med. 1993;329:1615-1622.

31. Gruppo Italiano per lo Studio della Sopravvivenza nell'Infarto Miocardico (GISSI). GISSI-2: a factorial randomised trial of alteplase versus streptokinase and heparin versus no heparin among 12,490 patients with acute myocardial infarction. Lancet. 1990;336:65-71.

32. The International Study Group. In-hospital mortality and clinical course of 20,891 patients with suspected acute myocardial infarction randomised between alteplase and streptokinase with or without heparin. Lancet. 1990;336:71-75.

33. ISIS-3 (Third International Study of Infarct Survival) Collaborative Group. ISIS-3: a randomised comparison of streptokinase vs tissue plasminogen activator vs anistreplase and of aspirin plus heparin vs aspirin alone among 41,299 cases of suspected acute myocardial infarction. Lancet. 1992;339:753-770.

34. The GUSTO Investigators. An international randomized trial comparing four thrombolytic strategies for acute myocardial infarction. N Engl J Med. 1993;329:673-682.

35. Gold HK. Conjunctive antithrombotic and thrombolytic therapy for coronary-artery occlusion. $N$ Engl J Med. 1990;323:1483-1485.

36. Sobel BE, Hirsh J. Principles and practice of coronary thrombolysis and conjunctive treatment. Am J Cardiol. 1991;68:382-388.

37. Bleich SD, Nichols TC, Schumacher RR, Cooke DH, Tate DA, Teichman SL. Effect of heparin on coronary arterial patency after thrombolysis with tissue plasminogen activator in acute myocardial infarction. Am J Cardiol. 1990;66:1412-1417.

38. Ohman EM, Califf RM, Topol EJ, Candela R, Abbottsmith C, Ellis S, Sigmon KN, Kereiakes D, George B, Stack R. Consequences of reocclusion after successful reperfusion therapy in acute myocardial infarction. Circulation. 1990;82:781-791.

39. Hsia J, Hamilton WP, Kleiman N, Roberts R, Chaitman BR, Ross AM for the Heparin-Aspirin Reperfusion Trial (HART) Investigators: A comparison between heparin and low-dose aspirin as adjunctive therapy with tissue plasminogen activator for acute myocardial infarction. N Engl J Med. 1990;323:1433-1437.

40. de Bono DP, Simoons ML, Tijssen J, Arnold AER, Betriu A, Burgersdijk C, Lopez-Bescos L, Mueller E, Pfisterer M, Van de Werf F, Zijlstra F, Verstraete M, for the European Cooperative Study Group (ECSG). Effect of early intravenous heparin on coronary patency, infarct size and bleeding complications after alteplase thrombolysis: results of a randomized double blind European Cooperative Study Group trial. Br Heart J. 1992;67: 122-128.

41. Gouin I, Lecompte T, Morel MC, Lebrazi J, Modderman PW, Kaplan C, Samama MM. In vitro effects of plasmin on human platelet function in plasma. Circulation. 1992;85:935-941.

42. Melandri G, Branzi A, Semprini F, Cervi V, Galie N, Magnani B. Enhanced thrombolytic efficacy and reduction of infarct size by simultaneous infusion of streptokinase and heparin. Br Heart J. 1990;64:118-120.

43. Meijer A, Werter CJ, Verheugt FWA, Lie KI, van der Pol JMJ, Michels HR. The APRICOT Study: aspirin versus coumadin in the prevention of recurrent ischemia and reocclusion after successful thrombocysts: a placebo-controlled angiographic follow-up study. I Am Coll Cardiol. 1992;19:91A.

44. Kidker PM, Hebert PR, Fuster V, Hennekens $\mathrm{CH}$. Are both aspirin and heparin justified as adjuncts to thrombolytic therapy for acute myocardial infarction? Lancet. 1993;341:1574-1577.

45. Buchwald AB, Sandrock D, Unterberg C, Munz DL, Wiegand V. Hirudin vs heparin for the prevention of platelet deposition on coronary stents. J Am Coll Cardiol. 1992;19:47A. Abstract.

46. Cannon CP, Ganz P, Selwyn AP, Eddings K, Fox I, Maraganore $\mathrm{J}$, Braunwald E. Use of Hirulog-1, a novel thrombin inhibitor, to anticoagulate patients during cardiac catherization. $\mathrm{J} \mathrm{Am}$ Coll Cardiol. 1992;19:60A. Abstract.

47. Zoldhelyi P, Chesebro JH, Webster MWI, Grill DE, Gaspar D, Edwards SJ, Cabot CF, Fuster V. Recombinant desulfato hirudin, a specific antithrombin in patients with chronic stable coronary disease: effect on hemostatic parameters. J Am Coll Cardiol. 1992; 19:104A. Abstract.

48. Walsh D, Rote W, Bates E, Mu DX, Nedelman M, Lucchesi B. The 7E3 glycoprotein IIb/IIIa antibody prevents reocclusion and 
death post-TPA-induced thrombolysis in a chronic canine model of coronary thrombosis. J Am Coll Cardiol. 1992;19:330A. Abstract.

49. Yao S-K, Ober JC, Anderson HV, Ferguson JJ, Maraganore J, Buja LM, Willerson JT. Combined thrombin inhibition and thromboxane $\mathrm{A}_{2}$ synthesis and receptor blockade enhances thrombolysis and delays arterial reocclusion. J Am Coll Cardiol. 1992;19:329A. Abstract.

50. Marder VJ. Inhibiting and inhibitor. Circulation. 1992;85:386-387. Editorial.

51. Levi M, Biemond BJ, van Zonneveld AJ, ten Cate JW, Pannekoek $H$. Inhibition of plasminogen activator inhibitor-1 activity results in promotion of endogenous thrombolysis and inhibition of thrombus extension in models of experimental thrombosis. Circulation. 1992;85:305-312.

52. Maggioni AP, Franzosi MG, Santoro E, White H, Van de Werf F, Tognoni $\mathrm{G}$. The risk of stroke in patients with acute myocardial infarction after thrombolytic and antithrombotic treatment. N Engl J Med. 1992;327:1-6.

53. Levine MN, Goldhaber SZ, Califf RM, Gore JM, Hirsh J. Hemorrhagic complications of thrombolytic therapy in the treatment of myocardial infarction and venous thromboembolism. Chest. 1992;102(suppl):364S-373S.

54. Gore JM, Sloan M, Price TR, Randall AM, Bovill E, Collen D, Forman S, Knatterud GL, Sopko G, Terrin ML. Intracerebral hemorrhage, cerebral infarction and subdural hematoma after acute myocardial infarction and thrombolytic therapy in the Thrombolysis in Myocardial Infarction Study. Circulation. 1991; 83:448-459.

55. Topol EJ, Califf RM, George BS, Kereiakes DJ, Abbottsmith CW, Candela RJ, Lee KL, Pitt B, Stack RS, O'Neill WW. A randomized trial of immediate versus delayed elective angioplasty after intravenous tissue plasminogen activator in acute myocardial infarction. $N$ Engl $J$ Med. 1987;317:581-588.

56. Rao AK, Pratt C, Berke A, Jaffe A, Ockene I, Schreiber TL, Bell WR, Knatterud G, Robertson TL, Terrin ML. Thrombolysis in Myocardial Infarction (TIMI) Trial-Phase I: hemorrhagic manifestations and changes in plasma fibrinogen and the fibrinolytic system in patients treated with recombinant tissue plasminogen activator and streptokinase. J Am Coll Cardiol. 1988;11:1-11

57. The TIMI Research Group. Immediate vs delayed catheterization and angioplasty following thrombolytic therapy for acute myocardial infarction. JAMA. 1988;260:2849-2858.

58. Califf RM, Topol EJ, George BS, Boswick JM, Abbottsmith C, Sigmon KN, Candella R, Masek R, Kereiakes D, O'Neill WW, Stack RS, Stump DC. Hemorrhagic complications associated with the use of intravenous tissue plasminogen activator in treatment of acute myocardial infarction. Am J Med. 1988;85:353-359.

59. The TIMI Study Group. Comparison of invasive and conservative strategies after treatment with intravenous tissue plasminogen activator in acute myocardial infarction: results of the Thrombolysis in Myocardial Infarction (TIMI) phase II trial. $N$ Engl $J$ Med. 1989;320:618-627.

60. Stafford PJ, Strachan CJ, Vincent R, Chamberlain DA. Multiple microemboli after disintegration of clot during thrombolysis for acute myocardial infarction. Br Med J. 1989;299:1310-1312.

61. De Bono DP, Pocock SJ, the SWIFT (Should We Intervene Following Thrombolysis?) Trial Study Group. SWIFT trial of delayed elective intervention vs conservative treatment after thrombolysis with anistreplase in acute myocardial infarction. $\mathrm{Br}$ Med J. 1991;302:555-560.

62. Price TR. Stroke in patients treated with thrombolytic therapy for acute myocardial infarction: the thrombolysis in myocardial infarction clinical trial and a review of placebo-controlled trials. Stroke. 1990;21(suppl III):III-8-III-9.

63. Rawles JM. Risk-benefit analysis of thrombolytic therapy for acute myocardial infarction: a perspective. Coron Artery Dis. 1992; 3:1153-1161

64. DeWood MA, Spores J, Notske R, Mouser LT, Burroughs R, Golden MS, Lang HT. Prevalence of total coronary occlusion during the early hours of transluminal myocardial infarction. N Engl J Med. 1980;303:897-902.

65. Topol EJ. Mechanical interventions for acute myocardial infarction. In: Topol EJ, ed. Textbook of Interventional Cardiology. Philadelphia, Pa: WB Saunders; 1990:269-299.

66. Heras M, Thompson PL, Chesebro JH, Fuster V. Prevention of early and late rethrombosis and further strategies after coronary reperfusion. In: Julian D, Desmond G, Norris RM, Kübler W, Swan HJ, Collen D, Verstraete M, eds. Thrombolysis in Cardiovascular Disease. New York, NY: Marcel Dekker; 1989:203-229.
67. Rouleau JL, Moyé LA, Pfeffer MA, Arnold JM, Bernstein V, Cuddy TE, Dagenais GR, Geltman EM, Goldman S, Gordon D. A comparison of management patterns after acute myocardial infarction in Canada and the United States. N Engl J Med. 1993; 328:779-784.

68. Meyer J, Merx W, Schmitz H, Erbel R, Kiesslich T, Dörr R, Lambertz H, Bethge C, Krebs W, Bardos P, Minale C, Messmer BJ, Effert S. Percutaneous transluminal coronary angioplasty immediately after intracoronary streptolysis of transmural myocardial infarction. Circulation. 1982;66:905-913.

69. Erbel R, Pop T, Diefenbach C, Meyer J. Long-term results of thrombolytic therapy with and without percutaneous transluminal coronary angioplasty. J Am Coll Cardiol. 1989;14:276-285.

70. Simoons ML, Arnold AE, Betriu A, de Bono DP, Col J, Dougherty FC, von Essen R, Lambertz H, Lubsen J, Meier B. Thrombolysis with tissue plasminogen activator in acute myocardial infarction: no additional benefit from immediate PTCA. Lancet. 1988;1:197-203.

71. Arnold AE, Simoons ML, Van de Werf F, de Bono DP, Lubsen J, Tijssen JG, Serruys PW, Verstraete M. Recombinant tissue-type plasminogen activator and immediate angioplasty in acute myocardial infarction: one year follow-up. Circulation. 1992; 86:111-120.

72. Davies SW, Marchant B, Lyons JP, Timmis AD, Rothman MT, Layton CA, Balcon R. Coronary lesion morphology in acute myocardial infarction: demonstration of early remodeling after streptokinase treatment. J Am Coll Cardiol. 1990;16:1079-1086.

73. Harrison DG, Ferguson DW, Collins SM, Skorton DJ, Ericksen EE, Kioschos JM, Marcus ML, White CW. Rethrombosis after reperfusion with streptokinase: importance of geometry of residual lesions. Circulation. 1984;69:991-999.

74. Davies SW, Marchant B, Lyons JP, Timmis AD, Rothman MT, Layton CA, Balcon R. Irregular coronary lesion morphology after thrombolysis predicts early clinical instability. $\mathrm{J} \mathrm{Am} \mathrm{Coll} \mathrm{Cardiol.}$ 1991;18:669-674.

75. Rapaport E. Early versus late opening of coronary arteries: the effect of timing. Clin Cardiol. 1990;13(suppl 8):VIII 18-VIII 22.

76. Brodie BR, Stuckey TD, Hansen CJ, Cooper TR, Weintraub RA, Le Bauer EJ, Katz JD, Kelly TA. Importance of a patent infarctrelated artery for hospital and late survival after direct coronary angioplasty for acute myocardial infarction. Am J Cardiol. 1992; 69:1113-1119.

77. Ellis SG, O'Neill WW, Bates ER, Walton JA Jr, Nabel EG, Werns SW, Topol EJ. Implications for patient triage from survival and left ventricular functional recovery analyses in 500 patients treated with coronary angioplasty for acute myocardial infarction. J Am Coll Cardiol. 1989;13:1251-1259.

78. O'Keefe JH Jr, Rutherford BD, McConahay DR, Johnson WL Jr, Giorgi LV, Shimshak TM, Ligon RW, McCallister BD, Hartzler GO. Myocardial salvage with direct coronary angioplasty for acute infarction. Am Heart J. 1992;123:1-6.

79. Eckman MH, Wong JB, Salem DN, Pauker SG. Direct angioplasty for acute myocardial infarction: a review of outcomes in clinical subsets. Ann Intern Med. 1992;117:667-676.

80. Lee L, Bates ER, Pitt B, Walton JA, Laufer N, O'Neill WW. Percutaneous transluminal coronary angioplasty improves survival in acute myocardial infarction complicated by cardiogenic shock. Circulation. 1988;78:1345-1351.

81. Lee L, Erbel R, Brown TM, Laufer N, Meyer J, O'Neill WW. Multicenter registry of angioplasty therapy of cardiogenic shock: initial and long term survival. J Am Coll Cardiol. 1991;17:599-603.

82. Ruocco NA Jr, Bergelson BA, Jacobs AK, Frederick MM, Faxon DP, Ryan TJ. Invasive versus conservative strategy after thrombolytic therapy for acute myocardial infarction with antecedent angina: a report from Thrombolysis in Myocardial Infarction Phase II (TIMI II). J Am Coll Cardiol. 1992;20:1445-1451.

83. Terrin ML, Williams DO, Kleiman NS, Willerson J, Mueller HS, Desvigne-Nickens P, Forman SA, Knatterud GL, Braunwald E. Two - and three-year results of the Thrombolysis in Myocardial Infarction (TIMI) phase II clinical trial. J Am Coll Cardiol. 1993; 22:1763-1772.

84. DeWood MA, Spores J, Notske RN, Lang HT, Shields JP, Simpson CS, Rudy LW, Grunwald R. Medical and surgical management of myocardial infarction. Am J Cardiol. 1979;4: 1356-1364.

85. Mathey DG, Rodewald G, Rentrop P, Leitz K, Merx W, Messmer BJ, Rutsch W, Bucherl ES. Intracoronary streptokinase thrombolytic recanalization and subsequent surgical bypass of remaining atherosclerotic stenosis in acute myocardial infarction: complimentary combined approach affecting reduced infarct size, 
preventing reinfarction and improving left ventricular function. Am Heart J. 1981;102(suppl):1194-1201.

86. Kereiakes DJ, Califf RM, George BS, Ellis S, Samaha J, Stack R, Martin LH, Young S, Topol EJ. Coronary bypass surgery improves global and regional left ventricular function following thrombolytic therapy for acute myocardial infarction. Am Heart $J$. 1991;122:390-399.

87. Moosvi AR, Khaja F, Villanueva L, Gheorghiade M, Douthat L, Goldstein S. Early revascularization improves survival in cardiogenic shock complicating acute myocardial infarction. $\mathrm{J} \mathrm{Am}$ Coll Cardiol. 1992;19:907-914.

88. Volpi A, De Vita C, Franzosi MG, Geraci E, Maggioni AP, Mauri F, Negri E, Santoro E, Tavazzi L, Tagnoni G and the Ad hoc Working Group of the Gruppo Italiano per lo Studio della Sopravvivenza nell'Infarto Miocardico (GISSI)-2 Data Base. Determinants of 6-month mortality in survivors of myocardial infarction after thrombolysis: results of the GISSI-2 data base. Circulation. 1993;88:416-429.

89. Schlant RC, Forman S, Stamler J, Canner PL. The natural history of coronary heart disease: prognostic factors after recovery from myocardial infarction in 2789 men: the 5-year findings of the coronary drug project. Circulation. 1982;66:401-414.

90. Madsen EB, Gilpin E, Henning H. Evaluation of prognosis one year after myocardial infarction. J Am Coll Cardiol. 1983;1: 985-993.

91. Fioretti P, Brower RW, Simoons ML, ten Katen H, Beelen A, Baardman T, Lubsen J, Hugenholtz PG. Relative value of clinical variables, bicycle ergometry, rest radionuclide ventriculography and 24 hour ambulatory electrocardiographic monitoring at discharge to predict 1 year survival after myocardial infarction. $J \mathrm{Am}$ Coll Cardiol. 1986;8:40-49.

92. Stadius ML, Davis K, Maynard C, Ritchie JL, Kennedy JW. Risk stratification for 1 year survival based on characteristics identified in the early hours of acute myocardial infarction: the Western Washington Intracoronary Streptokinase Trial. Circulation. 1986; 74:703-711.

93. Simoons ML, Vos J, Tijssen JG, Vermeer F, Verheugt FW, Krauss XH, Cats VM. Long-term benefit of early thrombolytic therapy in patients with acute myocardial infarction. $\mathrm{J} \mathrm{Am}$ Coll Cardiol. 1989;14:1609-1615.

94. Multicenter Postinfarction Research Group. Risk stratification and survival after myocardial infarction. $N$ Engl J Med. 1983;309: 331-336.

95. Cleempoel H, Vainsel H, Dramaix M, Lenaers A, Contu E, Hoylaerts M, Demaret B, de Marneffe M, Vandenbossche JL, Renard M. Limitations on the prognostic value of predischarge data after myocardial infarction. Br Heart J. 1988;60:98-103.

96. ESC Working Group on Exercise Physiology, Physiopathology and Electrocardiography. Guidelines for cardiac exercise testing. Eur Heart J. 1993;14:969-988.

97. Touchstone DA, Beller GA, Nygaard TW, Watson DD, Tedesco C, Kaul S. Functional significance of predischarge exercise thallium-201 findings following intravenous streptokinase therapy during acute myocardial infarction. Am Heart J. 1988;116: 1500-1507.

98. Marx BE, Bertel O, Amann FW. Late recurrent ischaemia in infarct patients with a normal predischarge exercise test after thrombolysis. Eur Heart J. 1990;11:897-902.

99. Sutton JM, Topol EJ. Significance of negative exercise thallium test in the presence of a critical residual stenosis after thrombolysis for acute myocardial infarction. Circulation. 1991;83: 1278-1286.
100. Lette J, Laverdiére M, Cerino M, Waters D. Is dipyridamolethallium imaging preferable to submaximal exercise thallium testing for risk stratification after thrombolysis? Am Heart J. 1990; 119:671-672.

101. Beller GA. Noninvasive assessment of myocardial salvage after coronary reperfusion: a perpetual quest of nuclear cardiology. J Am Coll Cardiol. 1989;14:874-876.

102. Lavie CJ, Gibbons RJ, Zinsmeister AR, Gersh BJ. Interpreting results of exercise studies after acute myocardial infarction altered by thrombolytic therapy, coronary angioplasty or bypass. Am J Cardiol. 1991;67:116-120.

103. Haber HL, Beller GA, Watson DD, Gimple LW. Exercise thallium-201 scintigraphy after thrombolytic therapy with or without angioplasty for acute myocardial infarction. Am J Cardiol. 1993;71:1257-1261.

104. Dilsizian V, Bonow RO. Current diagnostic techniques of assessing myocardial viability in patients with hibernating and stunned myocardium. Circulation. 1993;87:1-20.

105. Tilkemeier PL, Guiney TE, LaRaia PJ, Boucher CA. Prognostic value of predischarge low-level exercise thallium testing after thrombolytic treatment of acute myocardial infarction. $\mathrm{Am} \mathrm{J}$ Cardiol. 1990;66:1203-1207.

106. Taylor GJ, Moses HW, Katholi RE, Korsmeyer C, Kolm P, Dove JT, Mikell FL, Sutton JM, Wellons HA, Schneider JA. Six-year survival after coronary thrombolysis and early revascularization for acute myocardial infarction. Am J Cardiol. 1992;70:26-30.

107. Arnold AE, Simoons ML, Van de Werf F, de Bono DP, Lubsen J, Tijssen JG, Serruys PW, Verstraete M, for the European Cooperative Study Group. Recombinant tissue-type plasminogen activator and immediate angioplasty in acute myocardial infarction: one-year follow-up. Circulation. 1992;86:111-120.

108. Gibson RS, Watson DD, Craddock GB, Crampton RS, Kaiser DL, Denny MJ, Beller GA. Prediction of cardiac events after uncomplicated myocardial infarction: a prospective study comparing pre-discharge exercise thallium-201 scintigraphy and coronary angiography. Circulation. 1983;68:321-336.

109. Beller GA, Gibson RS. Sensitivity, specificity, and prognostic significance of non-invasive testing for occult or known coronary disease. Prog Cardiovasc Dis. 1987;29:241-270.

110. Bolognese L, Sarasso G, Aralda D, Bongo AS, Rossi L, Rossi P. High dose dipyridamole echocardiography early after uncomplicated acute myocardial infarction: correlation with exercise testing and coronary angiography. J Am Coll Cardiol. 1989;14: 357-363.

111. Ryan T, Armstrong WF, O'Donnell JA, Feigenbaum H. Risk stratification after acute myocardial infarction by means of exercise two-dimensional echocardiography. Am Heart J. 1987; 114:1305-1316

112. McNeill AJ, Fioretti PM, el-Said EM, Salustri A, Forster T, Roelandt Jr. Enhanced sensitivity for detection of coronary artery disease by addition of atropine to dobutamine stress echocardiography. Am J Cardiol. 1992;70:41-46.

113. Abraham RD, Harris PJ, Roubin GS, Shen WF, Sadick N, Morris J, Kelly DT. Usefulness of ejection fraction response to exercise one month after myocardial infarction in predicting coronary anatomy and prognosis. Am J Cardiol. 1987;60:225-230.

114. Rogers WJ, Babb JD, Baim DS, Chesebro JH, Gore JM, Roberts R, Williams DO, Frederick M, Passamani ER, Braunwald E. Selective versus routine predischarge coronary arteriography after therapy with recombinant tissue-type plasminogen activator, heparin and aspirin for acute myocardial infarction. $\mathrm{J} \mathrm{Am}$ Coll Cardiol. 1991;17:1007-1016.

$\overline{\text { KEY WORDS } ・ \text { reperfusion } ・ \text { myocardial infarction } ・ \text { thrombolysis }}$ 